\title{
Analysis Mathematical Communication Skills Students In The Matter Algebra Based Nctm
}

\author{
Paridjo1,2, St. Budi Waluya2 \\ ${ }^{1}$ Universitas Pancasakti,Tegal: muhparidjo@gmail.com. id G71035 \\ ${ }^{2}$ Universitas Negeri Semarang, Semarang: s.b.waluya@mail.unnes.ac.id
}

\begin{abstract}
Mathematical communication in solving mathematical problems is necessary, based on observations of the tasks to students, there are still many who have not been able to communicate in solving problems. The purpose of writing this study was to analyze the students' ability in mathematical communication resolve algebra problems. The sample was a student of mathematics education FKIP Pancasakti University (UPS) Tegal from various secondary schools such as SMA / MA with various departments and SMK with various skills. The method used is a qualitative research with descriptive analysis. The data collection is done by providing a set of written test for solving linear algebra equations of one variable. The results are analyzed based on student performance indicators set by the NCTM (2000). The results of the study of mathematical abilities of students who have not been in accordance with the indicators, especially in organizing and accommodating mathematical thinking and to evaluate the mathematical thinking in solving algebra problems. Mathematical communication skills of students from high school science better than the students coming from high schools and vocational IPS. Students who have good communication skills, both also in solution mathematics problems
\end{abstract}

Keywords: mathematical communication, problem solving, thinking algebra

\section{Introduction}

Mathematical communication has an important role in the learning of mathematics, because through mathematical communication students can express, explain, describe, hearing that take students on a deep understanding of mathematics. As expressed by a number of experts who have been defines the notion, principles, and standards of mathematical communication. National Council of Teachers of Mathematics (NCTM: 1989) suggested that curriculum standards, mathematics as a means of communication (mathematics as communication) for grade 5-8 (SMP) is able to: (1) modeling the situation, either orally, in writing, the real , images, graphics, and algebra strategies; (2) reflect and clarify their own thinking about mathematical ideas and their relationship; (3) develop an understanding with his mathematical ideas into rules and definitions; (4) use the ability to read, listen to interpret and evaluate mathematical ideas; (5) discuss mathematical ideas, make conjectures and convincing arguments; (6) to appreciate the value, mathematical notation, and its role in the development of mathematical ideas.

To measure mathematical abilities required indicator-indiktor. Indicators mathematical communication abilities in mathematics according to NCTM (2000) the ability of the students are: (1) organize and consolidate mathematical thinking (mathematical thinking) them through communication; (2) communicate their mathematical thinking coherently (arranged logically) and clear to his friends, teachers and others; (3) analyze and evaluate the mathematical thinking (mathematical thinking) and the strategies used by another person; (4) use the language of mathematics to express mathematical ideas correctly.

Meanwhile, according to Sumarmo (2003), communication skills include the ability of the student (a) connecting the real objects, drawings, and diagrams into the idea of mathematics; (b) explain ideas, situations and relationships mathematical orally or in writing with real objects, pictures, graphs and algebra; (c) declare a daily occurrence in the language or math symbol; (d) listening, discuss, and write about mathematics; (D) read with comprehension or writing mathematical presentation; (E) make a conjecture, make arguments, formulating definitions and generalizations; (F) explaining and making inquiries about the math they have learned.

Pancasakti University (UPS) Tegal is one of the private high perguuan in Tegal that has the Faculty of Education (Guidance and Counseling) and one of the courses are math education. Data semester students of the academic year 2016/2016 the number of students of mathematics education listed are derived from SMA / MA IPA as much as 43\%, SMA / MA IPS as much as 17\% and SMK as much as 40\%. Besides UPS Tegal is the last option for students SMTA in Tegal and surrounding area to continue their education in college, Under such circumstances, it needs good learning process and sincerely for each teacher.

Having regard to the state of the stretcher, required a study to develop the ability komuniasi mathematics. Problem solving can help students to develop mathematical ability.The problems that can be asked is "how mathematical communication ability of students in algebra material by NCTM. 


\section{Communication Mathematically}

\section{B. Literature}

Mathematics is generally identical to the calculation of figures and formulas, giving rise to the notion that communication skills can not be built on learning mathematics. This assumption is of course not correct, because according to the Greenes and Schulman, mathematical communication has a role: (1) a central force for students in formulating mathematical concepts and strategies; (2) capital for student success and completion of the approach in the exploration and investigation of mathematics; (3) a place for students to communicate with his friends to obtain information, share their thoughts and discoveries, brainstorming, assess and sharpen ideas to convince others.

The ability to communicate becomes one of the conditions that plays an important role as it helps in the process of preparing the mind, connecting ideas with other ideas that can fill up the things lacking in the whole network of student ideas. Correspondingly, Lindquist (in Fitrie, 2002: 16) states that we need communication in math if you want to fully achieve social goals, such as mathematics literacy, lifelong learning, and mathematics for everyone.

While building a mathematical communication according to the National Center Teaching Mathematics (NCTM, 1989) provides benefits to students in the form of: (1) Modeling the situation by verbal, written, images, graphics, and algebra; (2) Reflecting and clarified in thinking about mathematical ideas in various situations; (3) Develop an understanding of mathematical ideas, including the role of definitions in mathematics (4) Using the skills of reading, listening, and writing to interpret and evaluate mathematical ideas; (5) The assessment of mathematical ideas through conjecture and convincing reasons; (6) Understanding the value of notation and the role of mathematics in the development of mathematical ideas.

Activities teachers to develop students 'mathematical communication skills, among others: (1) Listen attentively and see the students' ideas; (2) Investigate questions and tasks administered, interesting, and challenging students to think; (2) Ask students to respond and assess their ideas orally and in writing; (3) Assess the depth of understanding or idea expressed in the students' discussion; (4) Decide when and how to present mathematical notation in the language of mathematics in students; (5) Monitor student participation in discussions, deciding when and how to motivate each student to participate.

While indicators of students' skills in mathematical communication in the learning of mathematics by NCTM (2003) are: (1) communicate their mathematical thinking coherently (arranged logically) and clear to his friends, teachers and others; (2) use the language of mathematics to express mathematical ideas correctly; (3) organize and consolidate mathematical thinking (mathematical thinking) them through communication; (4) analyze and evaluate the mathematical thinking (mathematical thinking) and the strategies used by another person.

Within (1992) states communication skills becomes important when the discussion among the students do, where students are expected to proclaim, explain, describe, hear, ask and work together so that it can take students on a deep understanding of mathematics. Children are given the opportunity to work in a group in collecting and presenting data, they show good progress in their time listening to each other and the idea of one another, discuss it together and then deducing that becomes the opinion of the group. Turns out they learned most of communicating and construct their own knowledge.

Meanwhile, according to Sumarmo (2003) students' mathematical communication capabilities include: (1) connecting the real objects, drawings, and diagrams into the idea of mathematics; (2) explain ideas, situations and relationships mathematical orally or in writing with real objects, pictures, graphs and algebra; (3) declare a daily occurrence in the language or math symbol; (4) listen, discuss, and write about mathematics; (5) read with comprehension or writing mathematical presentation; (6) make a conjecture, make arguments, formulating definitions and generalizations; (7) describes and made inquiries about the math they have learned.

In general, mathematics within the scope of communication includes skills / ability to write, read, discussing and assessing, and discourse (discourse). Without communication in mathematics we would have a bit of information, data, and facts about the students in the process of understanding and application of mathematics. Sadiq (2004) "Mathematics is a very powerful communication tool, precise and unambiguous". For example, the notation $40 \times 4$ can be used to express a variety of things, such as:

- Mileage motorcycle for 4 hours at a speed of $40 \mathrm{~km} / \mathrm{h}$.

- The surface area of the pool with a length of 40 meters and a width of 4 meters

- Many of the wheels on the car 40

The above examples have shown that the notation $40 \times 4$ can express a different matter.

\section{Troubleshooting}

In addition to mathematical communication, problem solving is crucial in overcoming the problems of mathematics. Each man faces different problems. The problem occurs because the gap between expectation and 
reality that has not be solved or solved the problem. By Polya in Ratnaningsih (2003: 3) states that the process can be done at each step problem solving through the following questions:

1) Step understand the problem

What is known or what was being asked? What data are provided?

How about conditions? Could it be that the conditions stated in the form of equations or other relationships? Is the given conditions sufficient to locate in question? Is it not sufficient condition or the condition is excessive or conditions that contradict each other? Draw a picture and posts appropriate notation!

2) Step planning solutions (devising a plan). (a) Has there been any problem before? Or have no same or similar questions in another form? ; (b) Did you know about that is similar to this question? Which theory can be used in this matter; (c) Note that asked! Think about ever known with a question or a similar one !; (d) If no problems are similar to the questions that once completed, can the experience was used in the problem now? (e) Can the results and methods were then used here? What to look for other elements in order to utilize the original question? (f) Can repeat the question again? Can the state in another form? Return to the definition! (g) Suppose that new issues can not be resolved, think and solve similar problems!

3) Implement the calculation of (carrying out theplan). (a) How to implement the settlement plan and check each step, check that each step is correct ?; (B) How to prove that the measures selected are correct?

4) Check the return process and outcome (looking break). (A) How do I check the results obtained truth ?; (b) Can examined objections? Can the results sought by other means? (c) Can you see it at a glance? Can it be or how it is used for other matters?

To measure the ability of solving mathematical problems required several indicators. The indicator according Sumarmo (2012) as follows: (1) identify the elements that are known, asked, and the adequacy of the elements, (2) create a mathematical model, (3) implement a strategy to solve the problem within / outside of mathematics, (4) to explain / interpret results, (5) completing mathematical models and real problems, (6) use math significantly. According to George Polya explained in How to Solve It outlines put forward four main steps in solving the problem, namely: Understanding the problem, Devising a Plan, Carrying out the Plan, and Looking Back (Motter, 2010).

Based on the above, this research problem solving capabilities will be measured through students' ability to solve a problem by using the steps in solving problems by Polya, namely: (1) understand the problem, (2) plan solutions, (3) conduct settlement plan issues, and (4) checks back, arguing that strategy commonly used.

\section{Think Algebra (Algebraic Reasoning)}

In algebra students must stop thinking like counting in arithmetic and must learn to think algebraically.

Thinking algebraic or algebraic reasoning involves the formation of generalization of experience with numbers and calculations, formalizing ideide using meaningful symbols, and explore the concept of pattern and function. Broadly speaking, there are three aspects of algebraic thinking, which is a generalization (generalizations), pattern (patterns), and functions (functions (Van de Walle at all: 2010)

Algebraic Thinking is not a single idea but composed of different forms of the mind and the understanding of a symbol (Van de Walle at all: 2010).

Another opinion thinks algebra is found to generalize from the experience with numbers and calculations, formalize ideas with a system of symbols, and explores the concepts of patterns and functions (Kieran, Carolyn: 2004).

The components of algebraic thinking are presented in the following table:

Table component algebraic thinking (Kriegler, Shelley: 2008)

\begin{tabular}{|c|c|}
\hline Mathematical Thinking Tools & Fundamental Idea of Algebra \\
\hline $\begin{array}{l}\text { Keterampilan Pemecahan masalah: } \\
\text { 1. Menggunakan strategi pemecahan masalah } \\
\text { 2. Menyelidiki beberapa pendekatan/beberapa solusi } \\
\text { Keterampilan representasi : } \\
\text { 1. Menampilkan hubungan-hubungan secara visual, } \\
\text { secara numerik, dan secara verbal } \\
\text { 2. Menafsirkan informasi dalam representasi- } \\
\text { representasi } \\
\text { Keterampilan penalaran kuantitatif } \\
\text { 1. Menganalisis masalah untuk menggali dan } \\
\text { mengukur hal penting } \\
\text { 2. Penalaran deduktif dan induktif }\end{array}$ & $\begin{array}{l}\text { Algebra as a general arithmetic } \\
\text { 1. Conceptually based calculation strategies } \\
\text { 2. Ratio and proportion } \\
\text { 3. Estimates } \\
\text { Algebra as the language of mathematics } \\
\text { 1. The meaning of variables and variable expression } \\
\text { 2. Meaning solution } \\
\text { 3. Understand and use the properties of the number system } \\
\text { 4. Reading, writing, manipulating numbers and symbols using algebraic rules } \\
\text { 5. Using symbolic representations to manipulate formulas, expressions, } \\
\text { equations and inequalities. } \\
\text { Algebraic functions and mathematical modeling } \\
\text { 1. Finding, expressing, generalizing patterns and rules in the context of the } \\
\text { real world } \\
\text { 2. Representing mathematical ideas with menggnakan equations, tables, } \\
\text { graphs, or words } \\
\text { 3. Working with the pattern of input and out put } \\
\text { 4. Develop skills coordinate graph }\end{array}$ \\
\hline
\end{tabular}




\section{Methods}

The research design in this study is a qualitative research design that is used to describe the extent of mathematical communication skills in problem solving algebra. The subjects were students of mathematics education first half were 28 people who came out of high school science department numbering 12 people, high school social studies courses amounted to 6 students and SMK range of expertise were 10 students who were selected through random sampling techniques each 2 students. Proper data collection techniques, is expected to provide the results of proper research and accountable. The technique used in this study were (1) Test, the test used in this study to determine the extent of the student's mathematical communication skills algebra material. (2) Documentation, according to (Sugiono. 2015) document is a record of events that had passed. Documents in this study is used to get the name and number of students of the first semester of a course of study of mathematics education FKIP UPS Tegal. The results are analyzed based on student performance indicators set by the NCTM.

Indicators of communications under NCTM (2000) are (1) organize and consolidate mathematical thinking (mathematical thinking) them through communication; (2) communicate their mathematical thinking coherently (arranged logically) and clear to his friends, teachers and others; (3) analyze and evaluate the mathematical thinking (mathematical thinking) and the strategies used by another person; (4) use the language of mathematics to express mathematical ideas correctly.

These indicators need to be developed to facilitate the analysis of mathematical communication skills, the indicators used in the table below:

\begin{tabular}{|l|l|}
\hline \multicolumn{1}{|c|}{ Indicators mathematical communication } & Student competency in mathematical communication \\
\hline $\begin{array}{l}\text { 1. communicate their mathematical } \\
\text { thinking coherently (arranged logically) } \\
\text { and clear to his friends, teachers and others }\end{array}$ & $\begin{array}{l}\text { 1. Communicate mathematical thinking coherently } \\
\text { (arranged logically) friends, teachers and others }\end{array}$ \\
\cline { 2 - 2 } & $\begin{array}{l}\text { 2. Mathematical thinking clearly communicate to } \\
\text { his friends, teachers and others }\end{array}$ \\
\hline $\begin{array}{l}\text { 2. organize and consolidate mathematical } \\
\text { thinking (mathematical thinking) them } \\
\text { through communication }\end{array}$ & $\begin{array}{l}\text { 3. Organize mathematical thinking (mathematical } \\
\text { thinking) through communication }\end{array}$ \\
\cline { 2 - 2 } & $\begin{array}{l}\text { 4. Consolidate mathematical thinking } \\
\text { (mathematical thinking) through communication }\end{array}$ \\
\hline & $\begin{array}{l}\text { 5. The use of the language of mathematics to } \\
\text { express mathematical ideas correctly }\end{array}$ \\
\hline $\begin{array}{l}\text { 3. The use of the language of mathematics } \\
\text { to express mathematical ideas correctly } \\
\text { analyze and evaluate the mathematical } \\
\text { thinking (mathematical thinking) and the } \\
\text { strategies employed by others }\end{array}$ & $\begin{array}{l}\text { 6. Analyze mathematical thinking (mathematical } \\
\text { thinking) and the strategies employed by others }\end{array}$ \\
\cline { 2 - 2 } & $\begin{array}{l}\text { 7. Valuate the mathematical thinking (mathematical } \\
\text { thinking) and the strategies employed by others }\end{array}$ \\
\hline
\end{tabular}

\section{Research Instruments}

In this study, the research instrument in the form of a description about solving algebra problems on the subject of the application of one variable linear equations.

Problems created by the application of the everyday problems associated with linear Equality. Instruments for use are:

1. A trader bought three bags of rice, after being weighed three consecutive sacks that weighed 234 kilograms and in whole numbers. What is the weight of each bag!

2. Mr. Hartono family has two sons Joe and Jim. Joe twice the age of the age of Jim. Six years ago the age Joe lebh three times older than Jim. Specify the age of each!

3. A garden has a length of $80 \mathrm{~m}$ and a width of $60 \mathrm{~m}$. The outside of the park is made for uniform width sidewalks around the square. Size for sidewalks is $1 / 6$ of the garden area. What is the width of the sidewalk?

4. A grass football field will be cut by two officers Ade and Bandi. Ade can cut grass 4 hours. Bandi will be able to cut the grass at 5 o'clock. How long it takes them to mow the lawn if they cooperate.

Research result

\section{Results And Discussion}

The results of this study are grouped into three high school students who come from the IPA, IPS SMA and SMK various skills. Student job then analyzed based on the competence of the indicator communication skills $\operatorname{NCTM}(2000)$. 
The results of the study are presented in the following table:

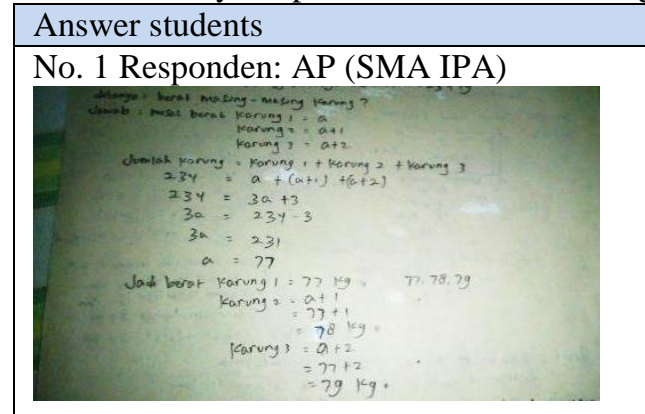
communication skills mathematical analysis

No. 1, respondents AP already have good communication skills mathematically, it is appropriate indicators. The ability to organize, consolidate, using the language of mathematics, and think coherently. AP shortcomings have not done an evaluation of its performance.

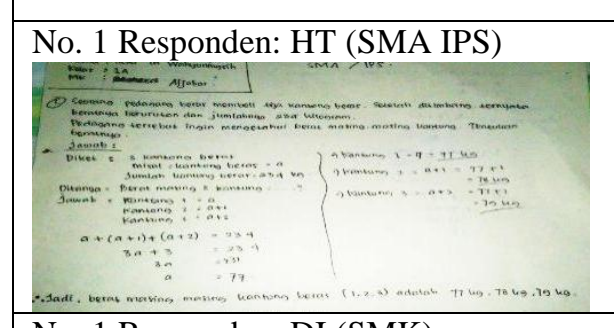

Respondents HT, have excellent communication skills, all the indicators set sdh fulfilled

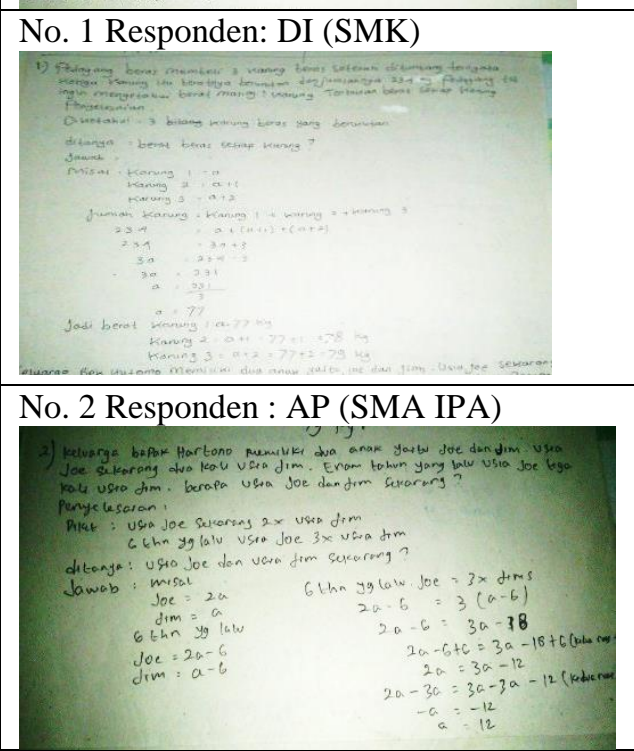

Respondents DI have excellent communication skills, all the indicators set sdh fulfilled

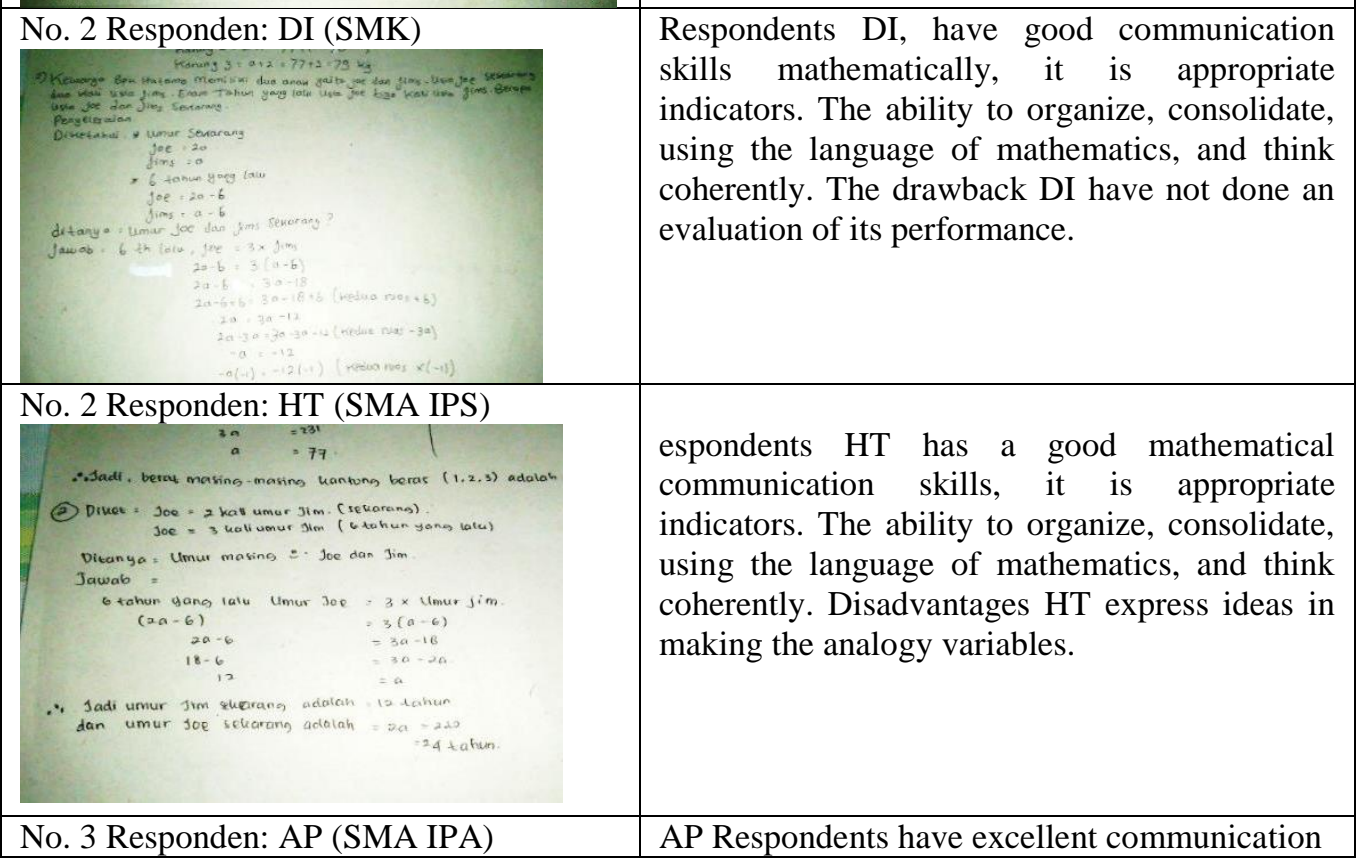




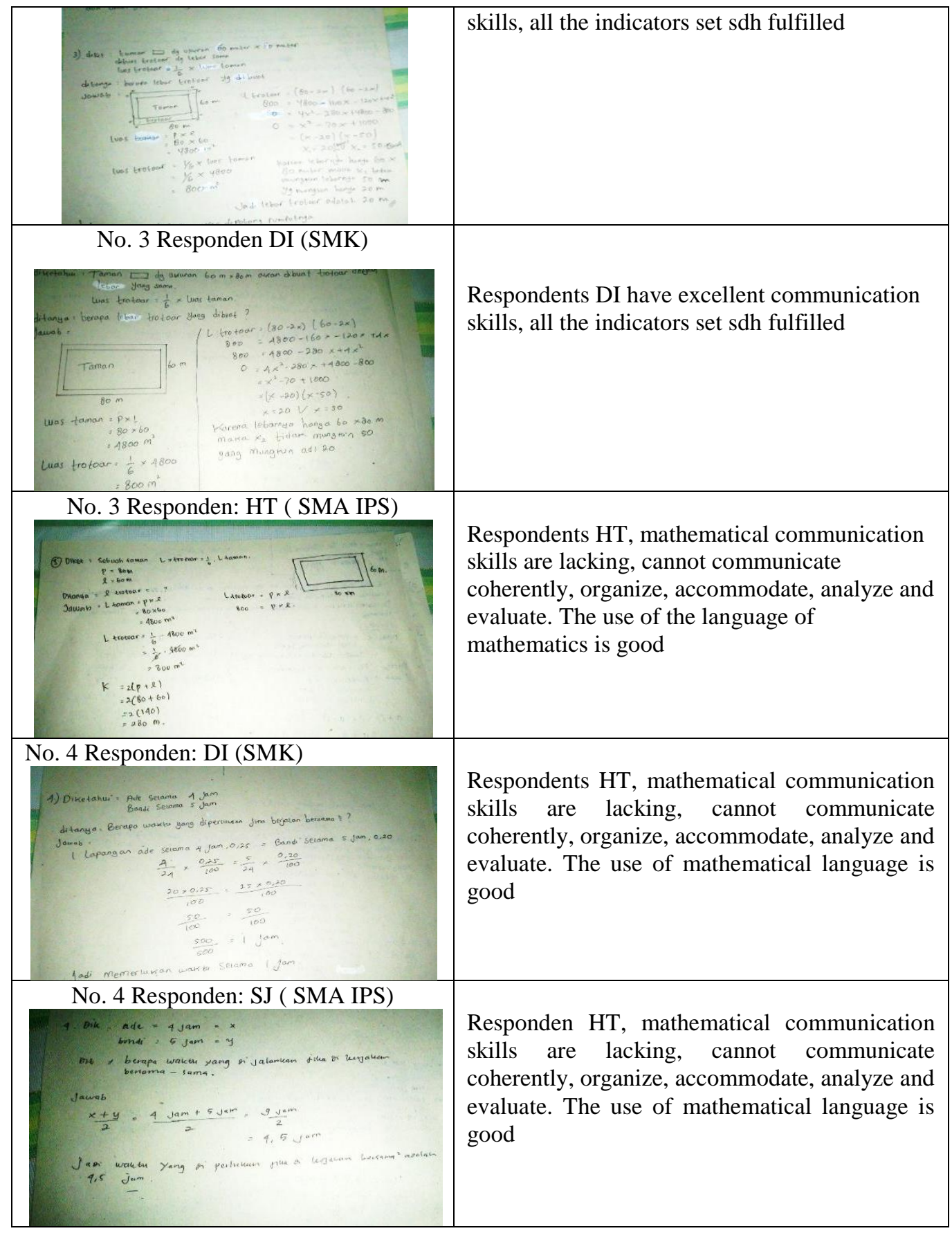

\section{Discussion}

Based on the analysis of student performance results in the table above, communication skills of students from SMA / MA with various departments and SMK with various expertise have different abilities, each has advantages and disadvantages in handling algebra problems. Students coming from high school science have better skills than students from IPS SMA and SMK in solving algebra problems. Likewise for mathematical communication skills of high school students who beasal IPA showed better results than students from high school and vocational IPA.

Respondents AP originated from high school science, have good communication skills is the ability to communicate mathematical thinking coherently danjelas, organize and accommodate mathematical thinking, using the language of mathematics to express mathematical ideas as well as to analyze and evaluate the mathematical thinking properly in accordance with the indicators NCTM (2000). This is in accordance with the opinion of Greenes and Schulman (Saragih, 2007) states that mathematical communication is: (a) a central force for students in formulating concepts and strategies; (B) capital for student success and completion of the approach in the exploration and investigation of mathematics; (C) a place for students to communicate with his 
friends to obtain information, share thoughts and discoveries, brainstorming, assess and sharpen ideas to convince others.For students from SMK showed better results than the high school students from IPS to solve mathematical problems and communication. As respondents HT students from SMK, have good communication skills is the ability to communicate mathematical thinking coherently danjelas, organize and accommodate mathematical thinking, using the language of mathematics to express mathematical ideas as well as to analyze and evaluate the mathematical thinking properly in accordance with the indicators NCTM (2000).

The weakness of students in mathematical communication is not yet melakakukan students to think mathematically evaluation on performance as did pleh respondents AP and AT. In addition, students have not been able to use mathematical language to express ideas in making the analogy of variables, this is done by the respondent HT.

\section{Conclusion}

Based on the results of this study concluded that students from SMA IPA has the ability to solve problems and mathematical communication better than students from high school and vocational IPS. Similarly, students who have good mathematical communication skills will have the ability to solve the problem well too.

\section{Bibliography}

[1]. Sugiyono, 2016. Research Methods Combined (Mixed Methods). Bandung: Alfabeta

[2]. Sugilar and Dada. 2011. Mathematics Education Research Methods. Jakarta: The Open University

[3]. Rahmawati, Fitriana. 2013, Influence of Realistic Mathematics Education approach dalamMeningkatkan Mathematical Communication Ability Elementary School Students. Semarang: Journal of the seminar, State University of Lampung (Download dated 29 November 2013

[4]. Lian, Lim Hooi and Yew, Wun Thiam. Developing Pre-algebraic Thinking in generalizing Repeating Pattern Using SOLO Model

[5]. Yun Lu. 2011. Using a Virtual Classroom to Teach Mathematics onine.

[6]. Hana, Ikhsan M and Fatimah, Siti. 2013. Upgrades and Communication Problem Solving mathematical Junior High School Students Through Cooperative Learning Model -Pair Think - Share.

[7]. Patricia McKane. 2011. Using VoiceThread for Communication in Mathematics Writing. New York: Institute of Technology. (Download dated December 5, 2016)

[8]. Abdul Qohar, UtariSumarmo. 2013. Improving Communication Mathematical Ability and Self Regulation Learning Of Junior High Students by Using Reciprocal Teaching. (IndoMS. J.M.E Vol. 4 No. 1 January 2013) (Download dated December 2, 2016)

[9]. Hasenbank, Jon F \& Hodgson, Ted. 2007. A Framework for Developing Algebraic Understanding and Procedural Skill: An Initial Assessment. Bonzemen: Department of Mathematical Sciences Montana State University

[10]. Sumirat, Lusi Ari. 2014.Efektifitas Strategies Cooperative Learning Think-Talk-Write (TTW) Of Communications And Disposition Mathematical Ability Students. Journal of Education and Teaching Vol. 1 No. 2, 2014 (downloadable 16 November 2016)

[11]. Sefalianti, Berta. 2014. Application of Guided Inquiry Approach Communications And Disposition Of Mathematical Ability Students. Journal of Education and Teaching Vol. 1 No. 2, 2014 (downloadable 30 November 2016)

[12]. Cathy Seeley. 2004. NCTM News Bulletin, September 2004 (downloaded 2 November 2016)

[13]. Abdul Qohar, UtariSumarmo. 2013. Improving Communication Mathematical Ability and Self Regulation Learning Of Junior High Students by Using Reciprocal Teaching. (IndoMS. J.M.E Vol. 4 No. 1 January 2013) (Download dated December 2, 2016)

[14]. Chap Sam Lim, Chin Mon, Chiew. 2008. Promoting Mathematical Thnking and Communivcation Billingual Classroom. University of malaysia

[15]. Hasenbank, Jon F \& Hodgson, Ted. 2007. A Framework for Developing Algebraic Understanding and Procedural Skill: An Initial Assessment. Bonzemen: Department of Mathematical Sciences Montana State University

[16]. Lian, Lim Hooi and Yew, Wun Thiam. Developing Pre-algebraic Thinking in generalizing Repeating Pattern Using SOLO Model

[17]. LIM, Chap Sam \& CHEW, Cheng Meng. 2007. Mathematical Communication in Malaysian Bilingual Classrooms. School of Educational Studies Universiti Sains Malaysia Penang, Malaysia. Paper to be presented at the 3rd APEC-Tsukuba International Conference: Innovation of classroom teaching and learning through study- lesson focusing on mathematical communication, December 9-14, 2007 at Tokyo and Kanazawa, Japan

[18]. Maolani, Rukaesih A and Cahyono, Ucu. 2015. Educational Research Methods. Jakarta: King Grafindo Persada

[19]. Patricia McKane. 2011. Using VoiceThread for Communication in Mathematics Writing. New York: Institute of Technology. (Download dated December 5, 2016)

[20]. Rahmawati, Fitriana. 2013, Influence of Realistic Mathematics Education approach dalamMeningkatkan Mathematical Communication Ability Elementary School Students. Semarang: Journal of the seminar, State University of Lampung (Download dated 29 November 2013

[21]. Sudjana. Nana \& Ibrahim. 2012. Research and Educational Assessment. Bandung: Sinar Baru Algesindo 